BEFORE / NOW

Vol. 1 No. 1

\title{
Links in the Chain: British slavery, Victoria and South Australia
}

\author{
By C. J. Coventry
}

KEYWORDS

Slavery; compensation; British West Indies; colonial

Victoria; provincial South Australia; Legacies of British Slave-ownership; place-names.
(C) The Author(s) [2019].

Published by the Collaborative Research Centre in Australian History, Federation University Australia. All rights reserved.

\begin{abstract}
Beneficiaries of British slavery were present in colonial Victoria and provincial South Australia, a link overlooked by successive generations of historians. The Legacies of British Slave-ownership database, hosted by University College, London, reveals many people in these colonies as having been connected to slave money awarded as compensation by the Imperial Parliament in the 1830s. This article sets out the beneficiaries to demonstrate the scope of exposure of the colonies to slavery. The list includes governors, jurists, politicians, clergy, writers, graziers and financiers, as well as various instrumental founders of South Australia. While Victoria is likely to have received more of this capital than South Australia, the historical significance of compensation is greater for the latter because capital from beneficiaries of slavery, particularly George Fife Angas and Raikes Currie, ensured its creation. Evidence of beneficiaries of slavery surrounds us in the present in various public honours and notable buildings.
\end{abstract}

\section{Introduction}

Until recently slavery in Australia was thought to be associated only with the history of Queensland and the practice of 'blackbirding'. However, the work undertaken by the Centre for the Study of the Legacies of British Slave-ownership at the University College, London, demonstrates the importance of slavery to the British Empire more generally. The UCL's Legacies of British Slave-ownership database catalogues the people who sought compensation from the Imperial Parliament for slaves emancipated in the 1830s, in recognition of their loss of property. Fortunes - or relative fortunes - were won even after human-property was confiscated. Emancipation was not purely the result of a great moral crusade, nor economic unviability, but a confluence of forces with momentous consequences. However, to compensate former slaveholders - to the tune of $£ 20,000,000$ at the time - was to state unambiguously that slavery was not, legally speaking, void. Instead, slaves were converted from property to people; their birth as humans resulted from legislation, not nature. To benefit financially from compensation was to take possession of the value of the slave and, therefore, acquire a direct financial benefit from slavery and the human suffering that entailed. It also affirmed a process that differentiated between the apparent quality of individual persons, with products being 'valued according to geography, gender and skill.' ${ }^{2}$ Yet, '[o]nly a few radical abolitionists objected to this payment of compensation, shocked that a campaign based on the immorality of owning people as property should come to this'. ${ }^{3}$

Beneficiaries of slavery arrived in Victoria and South Australia, as they did throughout the empire, freshly reimbursed. Using the Legacies database one can isolate individuals who journeyed to Victoria and South Australia and, from there, enquire as to who these people were and what prima facie influence they had on colonial development. In general, these beneficiaries of slavery possessed power and held prominence, consistent with the entitlement of wealthy people. Their influence is evidenced to this day in the grand buildings of Melbourne, in the towns of South Australia, as well as in- 
BEFORE / NOW

Vol. 1 No. 1

numerable place-names and statuary. But the greatest influence seems to have been exerted in the creation of South Australia.

Beneficiaries of slavery had a much greater presence in these colonies than previous research has indicated, including recent publications which explicitly identify various links. ${ }^{4}$ Before these publications, however, there was a generational averting of eyes by Australian scholars when it came to slavery. As Catherine Hall, one of the historians responsible for the Legacies database, described British history:

Forgetting is always an active process - whether the forms of memory are individual or collective... it is abolition that has been memorialised in Britain while slavery has been largely forgotten... Britons enjoyed congratulating themselves collectively on their magnificent gestures in ending the trade and then slavery, their 'gift' of liberty to others. What got erased was the two centuries of intimate involvement in the whole slavery business. ${ }^{5}$

What Hall had earlier called 'selective forgetting' - or others have called 'historical amnesia' and 'doublethink' - is a blight on history that must be treated with aggressive pruning. ${ }^{6}$ Otherwise, history remains wedded to past conclusions designed to perpetuate a society long since shown to be unjust and undemocratic. Present Victorians and South Australians are not responsible for the actions of their forbears, but they are responsible for how they choose to remember them. 'Anti-racism cannot coexist with narratives of the past that overlook links to slavery or, indeed, other atrocities. ${ }^{8}$ Until now the scale of exposure to slavery in colonial Australia - demonstrated by using the database - has been assumed.

\section{The Legacies database}

This article takes the primary source research conducted at UCL and contextualises it to demonstrate the breadth of exposure the colonies had to slavery. Bringing together the people who were beneficiaries of slavery enables future research to investigate links between these people, as well as the deeper ramifications to history of their presence. To construct this list a search was undertaken of the database of all those listed as having lived in Australia. This was done because the search function has numerous imperfections such that isolating individuals who lived in specific regions cannot be achieved reliably. Secondary sources have been used to show that a large portion of these people held high office. This approach reveals, for instance, the importance of slavery to the creation of South Australia. With respect to place-names, the author focuses on the position at law in order to ascertain whether they constitute a public honour or merely a name serving a purely administrative function. This was originally undertaken because of its relevance to the prima facie influence exerted by certain beneficiaries. The reason research was isolated to Victoria and South Australia was the personal connection the author shares with both states, having been raised in the latter and, at present, living in the former. Each colony is considered in turn with those judged by secondary sources to be influential beneficiaries discussed before mention is made of those seemingly less influential beneficiaries. In the case of persons who lived in both colonies, the colony they lived in first determines the section in which they are discussed.

The approach taken by the researchers at UCL's Legacies Centre was to use primary source documents, mostly parliamentary records, to identify individuals directly and indirectly connected to slave compensation awarded in the 1830 s upon emancipation. 
BEFORE I NOW

Vol. 1 No. 1

The subsequent database carefully lists the type of connection between compensation and beneficiary, as well as other pertinent primary source information like wills, loans, and familial connections, and earlier evidence demonstrating links to slavery prior to the award of compensation. As Hall explains:

Not all those who received compensation were directly involved in the ownership of plantations and people; mortgagees, annuitants and trustees all figured substantially. We have investigated the commercial and financial, political, cultural, historical, physical and imperial legacies of these men and women. ${ }^{9}$

Secondary source information is also referenced by the database. Although, Hall writes of the motivation behind the project:

The forgetting of slavery - part of the wider forgetting of race as a key marker of power and inequality - has fuelled the determination to put it back into British and imperial history and has been the motivating force behind the... project. ${ }^{10}$

The project is two-phased, with the first phase detailing beneficiaries of slavery completed. The second phase aims to capture the details of the enslaved persons. An integral part of Hall's argument is that:

Reparatory history must be about more than identifying wrongdoers and seeking redress: it begins with the descendants, with trauma and loss, but the hope is that the work of mourning can be linked to hopes for reconciliation, the repair of relations damaged by historical injustice. ${ }^{11}$

In highlighting various public honours this article demonstrates the story of slavery continues to the present. We use buildings built by beneficiaries, drive down streets and past statues that honour them, visit places that they knew, recite their poetry, or live in states and towns that owe a great deal to their actions. Yet, the word slavery features on no plaque, street sign, encyclopaedia, or tourist map.

This research into slavery and its repercussions throughout the empire has broader ramifications for Australian history and society at present. For example, place-names and statuary is a celebration of slaveholders and beneficiaries of slavery, and it occurs at the same time as the celebration of perpetrators of violence towards indigenous peoples. In this article beneficiaries are people linked to slavery, either through ownership of slaves, or by a financial or by close familial relationship. The link may be derived from circumstance or clear evidence of acquisition of capital, for example through a will. The reason for this assumption is the proximity to capital and high degree of likelihood that a benefit of some kind was derived. Conversely, the alternative argument - that explicit proof of financial benefit is required - would necessitate a clear financial record, one that is almost certainly in most instances lost to history. The Legacies Centre has also adopted this assumption.

\section{A brief history of British slavery}

In order to appreciate the significance of the links colonists had to slavery it is important to understand the context. While slavery was not unique to the British Empire it was utilised by it with tremendous skill. Western European slavery was ended by a combination of ecclesiastical and monarchical self-interest during the emergence of feudalism. ${ }^{12}$ Slavery of non-whites in England did not end until 1706, about a century before transatlantic slavery. ${ }^{13}$ As with slavery in Western Europe, the involvement of government was essential to the creation, maintenance and dismantling of transatlantic 
slavery. It was economically advantageous for the empire to use slave labour in the colonies of the West Indies and the Americas from the seventeenth century, as well as the East Indies and the Cape of Good Hope from the eighteenth century. ${ }^{14}$ The British programme involved the transportation of some 3.3 million people from the African continent on British ships, of course not including people born to slavery in the "New World'.15 Transatlantic slavery more generally - including British, Portuguese, Spanish, Dutch, American and French programmes - ultimately involved the forced transportation of some 12 million people from Africa over four centuries. ${ }^{16}$ The West Indies includes Honduras, Barbados, Jamaica, Antigua, the Bahamas, and Trinidad and Tobago, where over 90 per cent of the populations were non-white. ${ }^{17}$ It was the focal point of British slavery, second only to India..$^{18}$ The wealth generated by the West Indies 'far exceeded that of British North America'.19

The abolition of slavery movement was prominent by the 1790s. Slavery in its own time - especially during long years of abolition and emancipation - was morally reprehensible to many, including highly influential people such as philosophers Adam Smith and Thomas Paine. ${ }^{20}$ Yet, there has long been debate as to whether abolition of the slave trade and emancipation of slaves - some 30 years later - was the result of economic inevitability, humanitarian activism, pre-emption of 'black agency and resistance', or part of a reformation of the empire..$^{21}$ Certainly, Smith's argument that genuine free movement of labour was essential to capitalism influenced the bourgeoisie at the birth of capitalism - itself a government initiative - in the $1830 \mathrm{~s} .{ }^{22}$ It is beyond the scope of this article to determine what caused the abandonment of slavery; however, prima facie there was a confluence of forces. Taken together, it can be seen that the superior tactics of the abolitionists responding to favourable circumstances, especially fears of slave revolt, was instrumental to the abolition of the slave trade in 1807.23 Slaves were not emancipated until 1834 (the law having been changed in 1833) and truly emancipated until 1838. The reason for this delay was both political and economic. ${ }^{24}$ Since abolition a 'third way' or 'cultural imperialism' had emerged, which cautiously experimented with the amelioration of slavery, and economic protectionist beliefs also predominated. ${ }^{25}$ Again, the manoeuvrings of the abolitionists were crucial. ${ }^{26}$ By 1825, public outrage at the mistreatment of West Indian slaves produced a desire for emancipation, with a dramatic increase in popular activism which translated into political change. ${ }^{27}$ 'Probably more' than a fifth of all males over 15-years-of-age signed an emancipation petition in the late $1820 \mathrm{~s},{ }^{28}$ although, women maintained the cause through seemingly less popular periods. ${ }^{29}$ Compensation and the effective maintenance of slavery through unpaid six-year apprenticeships (excluding Antigua) were 'highly contentious' concessions to the slave-lobby, the West Indian Interest. ${ }^{30}$ It was not until 1838 that the apprenticeships - which were in fact an extreme form of slavery - ended in the West Indies; again, cunning activism was an important feature. ${ }^{31}$ Once slavery was ended new methods were adopted to oppress an expanded working class and the struggle genuine egalitarianism continued. ${ }^{32}$ Importantly, former proponents of slavery 'hurried to abandon a West Indian identity... unsullied by connections with slavery'. ${ }^{33}$ As a result of emancipation, the empire 'despatched human and financial capital to the East Indies, Canada and Australasia. ${ }^{34}$ British slavery was not inconsistent with the modus operandi of an empire which was, demonstrably, one of the most consequential and brutal in human history, 'full... of conquest, violence and terror'. 35

\section{The Colony of Victoria}

The Port Phillip District, part of New South Wales, existed for some 15 years before the separate Colony of Victoria officially came into existence in $1851 .{ }^{36}$ The region was 
BEFORE I NOW

Vol. 1 No. 1

known throughout the empire as Australia Felix ('Happy Australia') for its immense natural beauty and abundance. ${ }^{37}$ The first colonisers sought their riches from its fertile lands, while the first Victorians sought their riches in from its riverbeds and deep leads. ${ }^{38}$ Within years of its creation the colony had achieved self-government and considerable independence from the Crown. ${ }^{39}$ This section will consider a number of colonial Victorians who were beneficiaries of slavery. Of those mentioned, over half were people who held influential positions in society. Overall, Victorian beneficiaries varied considerably in terms of their power and influence, from a serial governor through to an Avoca farmer.

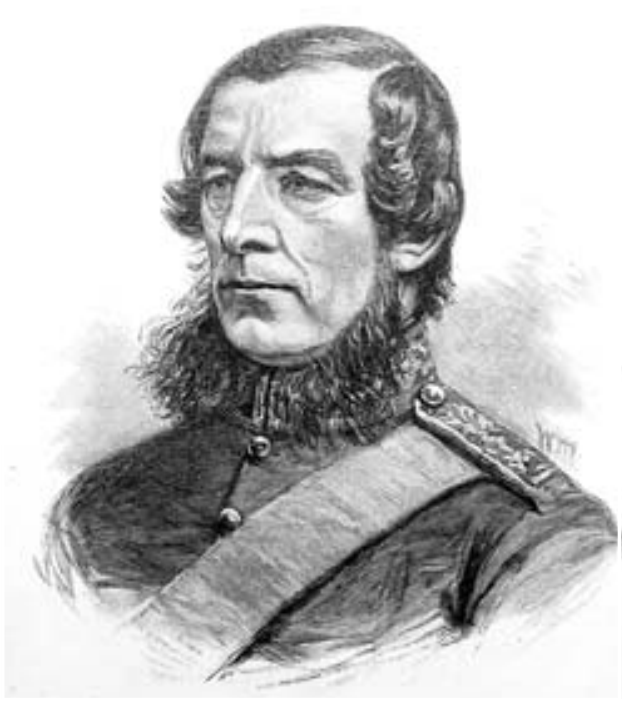

Henry Barkly, Governor of Victoria.

William Macleod, Sir Henry Barkly, c1886.

First published in Picturesque Atlas of Australia.

Ballarat Heritage Services Picture Collection, 00030.
The most prominent beneficiary of slavery in Victoria was Sir Henry Barkly, the colony's second governor. He served from 1856 to 1863, the longest period of service by anyone in the position until the record was surpassed in 1946. At the time the position received the "highest salary in the empire because the Colonial Office considered the post particularly difficult'.40 In Victoria he helped establish the Royal Society, the National Gallery and the National Observatory. ${ }^{41}$ Barkly was a serial governor of British colonies, having also served in Jamaica, Mauritius, and British Guiana, as well as High Commissioner for Southern Africa. ${ }^{42}$ Barkly's link to slavery is strong. His father, Sir Aeneas Barkly, and two business associates were awarded $£ 132,000$ in compensation for some 4,400 slaves located in the Caribbean and South America. ${ }^{43}$ Although they only held a portion of those slaves, they were mostly successful in claiming the amounts as creditors of slaveholders through the business dealings of their partnership, Davidsons, Barkly \& Co. Barkly Snr. was a director of the Colonial Bank when it started in $1836 .{ }^{44}$ Henry Barkly was an investor of the partnership but was also awarded some $£ 6,600$ for two compensation claims. ${ }^{45}$ Barkly inherited his father's estate in 1836 at the age of 20 . It may have been diminished as there are some indications the financial situation of the partnership was imperfect. ${ }^{46}$ Certainly, the estate was complex and Barkly took until 1843 to divorce himself from the partnership, which may have been related to various contractual arrangements. ${ }^{47}$ For example, he helped the plantation replace apprentices with indentured labourers from Kolkata in 1837, with their contracts ending in $1843 .{ }^{48}$

The Barkly name is ubiquitous in Australia. There is a Barkly Street in St Kilda and Elwood, including numerous associated placenames like Barkly Backpackers and Hotel Barkly.9 There is also the Sir Henry Barkly Hotel in Heidelberg, Barkly International College on Lonsdale Street, Barkly Street in Footscray and Brunswick, and Barkly Gardens in Richmond. Further afield is the village of Barkly, Victoria, and Barkly Street in Ballarat; there, the Barkly Motorlodge has a Sir Henry Function Room. Even further afield is the expansive Barkly Tableland in the Northern Territory and Queensland. ${ }^{50}$ The genus Barklya was named after Barkly by Ferdinand von Mueller and includes Barklya syringifolia ('Crown of Gold' or 'Gold Blossom Tree)' found throughout Coastal Queensland. ${ }^{51}$

The controversial governor, Sir Charles Henry Darling, was the third person to possess the title; he was often called 'the people's governor'. ${ }^{52}$ His first wife was Anne Wilhelmina (née Dalzell) who was a slaveholder in Barbados and, according to her will in 1838 , left some $£ 7,000$ in associated funds to her husband. ${ }^{53}$ But Darling came from a family of slaveholders himself, although there is nothing to suggest he personally benefited from this per se. ${ }^{54}$ The genus Darlingia was named in honour of Darling, 
again by von Mueller. ${ }^{55}$ It is also quite likely that Darling Gardens, Clifton Hill, is named in his honour as are potentially numerous streets in Melbourne, including Darling Street in South Yarra. ${ }^{56}$

Sir Edward Eyre Williams dominated early legal practice at the 'original Port Phillip bar' in the 1840s and then the early Victorian bar in the 1850s..$^{57}$ This was in large part because he had been 'able to remain on friendly terms' with the notoriously difficult judge, Walpole Willis. ${ }^{58} \mathrm{He}$ quickly became the Solicitor-General of the Colony of Victoria - and therefore a member of the Legislative Council - and then the second puisne justice of the Supreme Court of Victoria, where he wore the ermine for over 21 years. ${ }^{59} \mathrm{His}$ advancement arose during the Victorian gold rush, which had dramatically expanded the volume of cases before the judiciary. ${ }^{60} \mathrm{He}$ helped the church spread throughout Melbourne, was instrumental in establishing Royal Melbourne Hospital and built Como House, which is located on Williams Road, the border between Toorak and South Yarra, Melbourne. ${ }^{61}$ The land upon which the hospital rests to this day appears to be symbolically held in part by Williams's heirs. ${ }^{62}$

This eminent Melbournian was a slaveholder. Williams and a business associate held on trust $£ 3,146$ in compensation for 64 slaves, the beneficiary of which was his insane brother, Richard. ${ }^{63}$ But his father, Burton, is recorded to have owned 'at least 450 slaves' with his sons on their Bahamas sugar plantation in $1821 .{ }^{64}$ Indeed, before joining the bar he 'is said to have intended to become a colonial landowner himself'.65 Williams's son, Hartley, was another 'prominent member of the Victorian bar' and became the ninth puisne justice of the Supreme Court. ${ }^{66}$ His house, Flete, is in Armadale, Melbourne. ${ }^{67}$

Among other notable Victorians is Godfrey Downs Carter, who was a member of the Legislative Council and the Legislative Assembly, a director of the Bank of Victoria and a mayor of Melbourne. ${ }^{68} \mathrm{He}$ was notorious for his time as treasurer of Victoria during the Australian banking crisis of $1893-94 .{ }^{69}$ He was the eldest known son of John A. Carter who received $£ 126$ in compensation for six slaves held in Jamaica in 1837 as well as holding slave compensation money on trust. ${ }^{70}$ It is possible he benefited from slavery through his father, who died in 1870.11 Godfrey Carter also had an aunt, Dorothy Simes Carter, who had held eight slaves for which she had been compensated $£ 217$ in 1835 .2 $^{72}$ Another prominent Victorian was James Graham, who was a businessman, president of the Melbourne Club and a member of the Legislative Council.73 In 1845 he married Mary Alleyne Cobham, who successfully sought the recovery of a debt through a $£ 42$ compensation claim for two slaves held by her debtor. ${ }^{74}$

Arthur Lloyd Windsor, who was editor of the Argus, from 1863 to 1865, editor of the Age, from 1872 to 1900 - by far the longest serving person in that position - as well as editor of the Mount Alexander Mail in Castlemaine, was a beneficiary of slavery. ${ }^{75}$ One obituary suggests he had considerable influence over policy and legislation in Victoria at the time.$^{76}$ His father, Henry George Windsor, was compensated $£ 318$ for 14 slaves he held in Barbados in 1836.77 Arthur Windsor was five when his father died and spent most of his formative years in Barbados. ${ }^{78}$ Another probable beneficiary was Virginius Murray who was a police magistrate during the Victorian gold rush whose father, Alexander, had received some $£ 684$ compensation in $1836 .^{79}$

Charles Edward Bright was a prominent businessman in Melbourne and the son-in-law of governor Sir John Manners-Sutton, the Viscount Canterbury. ${ }^{80}$ Bright purchased Beleura House in Mornington, Melbourne, soon after it was built and it became the 'unofficial summer retreat' of the governor. ${ }^{81}$ His family had benefited directly from slavery. ${ }^{82}$ Robert Bright, his father, received part of some $£ 9,000$ in compensation. ${ }^{83}$ 
BEFORE I NOW

Vol. 1 No. 1

There is said to be ample primary source evidence that links the Bright family directly with slavery in the West Indies. ${ }^{84}$ The politician and businessman Charles Hotson Ebden MLC was the first pastoralist to cross the Murray River - in search of his slice of Australia Felix - one of the first landowners in Melbourne - buying expensive lots at Collins Street - the first Auditor-General of Victoria, as well as its sixth treasurer. ${ }^{85} \mathrm{He}$ built Black Rock House, which is on Ebden Street, in Black Rock, Melbourne, and is owned by Bayside City Council. ${ }^{86}$ The house was a holiday retreat and was the unofficial residence of Governor Barkly. ${ }^{87}$ It is possible Ebden Street in Ballarat is also named in honour of him. His father, John Bardwell Ebden, was a slaveholder who was compensated $£ 231$ for four slaves in $1836 .{ }^{88}$ Charles Wightman Sievwright was also present in the society of Port Phillip District and became a 'protector of Aborigines' overseeing 'what would later become the Western District of Victoria', from Geelong. ${ }^{89}$ He is said to have been dismissed from that role because of his advocacy for Indigenous peoples under his authority. His father, Andrew, received compensation arising from his financial affairs, although the precise amount is unclear. ${ }^{90}$

Another probable beneficiary of slavery was Edward Astley Cave, a Melbourne businessman, whose uncle was the brother of British prime minister, Benjamin Disraeli. His father, John Cave of Brentry, received part of the $£ 1,984$ compensation awarded to an estate of which his wife was a beneficiary; it held 137 slaves. ${ }^{91}$ A pioneer of Victorian theatre, Arthur Garner, was also a probable beneficiary of slavery through his grandfather, Nicholas Russell Garner. ${ }^{92}$ He had been compensated a portion of £2,239 for 112 slaves he held jointly in Barbados. ${ }^{93}$ Arthur helped build the Princess Theatre on Spring Street, Melbourne. ${ }^{94}$ The firm Miles, Kingston \& Co. 'refocused' its business on Melbourne after the emancipation of slavery, for which it was compensated around $£ 35,000$ as mortgagee and slaveholder. ${ }^{95}$ Another beneficiary was Robert Graham, of whom very little is known, but whose father, Captain Duncan Graham, received £2,423 in compensation for his 93 slaves in $1835 . .^{96}$ Similarly, John Hylton of Melbourne was awarded $£ 446$ for his 20 slaves held in Jamaica. ${ }^{97}$ Robert Elias Wallen was potentially a beneficiary of slavery because his father was compensated $£ 64$ for his slave in $1836 .{ }^{98}$ Melbournite, Alexander Chrystie, inherited money from his father, William Chrystie, who was a slaveholder whose business was compensated some $£ 12,000 .{ }^{99}$

Andrew and Celia Scott settled at the foot of Mt. Buninyong in 1839. In 1791 they had both been beneficiaries of the will of a Mr. Bird. ${ }^{100}$ However, it appears they did not receive all they were entitled to under law until various claims were made on a Tobago plantation with 107 slaves in 1836 by a third party. ${ }^{101}$ The Scotts and, possibly, four relatives comprised six of the seven awardees of the $£ 2,100$ in compensation, although together they received half that amount. ${ }^{102}$ Part of their station became the village of Scotsburn, near Ballarat. ${ }^{103}$ Interestingly, the property was still farmed by descendants until at least 2004. ${ }^{104}$ John King Fleming was a grazier with property at Antwerp, near Horsham, and Mt. Pleasant, in Ballarat. ${ }^{105}$ His father, John Sr., and mother, Maria, were involved with the aforementioned Scott family award. ${ }^{106}$

A less prominent beneficiary of slavery was William Shiell of Homebush who settled near Avoca, Victoria, in 1853.107 His grandfather, Queely Shiell, was a slaveholder of some 857 slaves and was compensated £13,900 in 1836.108 He left the planation to his three slave-owning children, including William Shiell Snr., in 1847.109 William Snr. was one of seven awardees of $£ 300$ in compensation in 1836.110 But William Jnr. was his illegitimate son, which suggests he was not a beneficiary. His mother was Mary Macnamara, a freewoman shopkeeper, who owned six slaves and was compensated $£ 102$ in 1836. ${ }^{111}$ Other beneficiaries include the family of a John Gregory, who migrated to Victoria in the 1850 s having inherited some $£ 1,000$ from his slaveholdings. ${ }^{112}$ 
Finally, Hall writes of two Victorians with connections to slavery. One was the author Henry Kingsley, brother of Charles Kingsley, who 'stayed [in Victoria] for five years... working on a sheep farm for a period and trying his hand, with very little success, at gold digging'.113 The other was John Price, Victoria's inspector-general of penal establishments who came from a family of 'major slave-owners in Jamaica'.14 He helped Victoria's stockades turn into prisons, beginning the protracted modernisation of Pentridge and the country gaols, with the aim of replacing the hulks - made especially brutal under his management - which may have been the same hulks that later housed reformatory schools for children.115 The mammoth modernisation projects ended in 1864. ${ }^{116}$ But his dream of deriving great profit from convict labour, a form of slavery presently practised in Australia, the United Kingdom and the United States, was not realised before he was stoned to death in 1857.117

\section{The Province of South Australia}

At the same time as Melbourne was being built and Australia Felix was being divided, South Australia was being negotiated in Whitehall. But the ambitions that led to its creation were somewhat grander in scale, possessed as they were by the likes of Protestant Dissenters and middle-class financiers. Initially, they had wanted a new state largely independent from the Crown but this was rejected. ${ }^{118}$ However, the separation of church and state was allowed. ${ }^{119}$ After setbacks and wrangling, the Imperial Parliament passed the South Australia Act of 1834. In 1836 the province - a term purely 'used to distinguish the settlement from the existing convict colonies of Australia' came into existence. ${ }^{120}$ This section will consider the South Australians who were beneficiaries of slavery listed on the Legacies database. Unlike Victoria, these beneficiaries almost entirely achieved power and influence in the province.

George Fife Angas was a significant founding father of South Australia largely because of his injection of finance during the early decades of the colony, as well as his zealotry. ${ }^{121}$ With his keen investor's eye he eagerly forced his interests ahead of others. ${ }^{122}$ His real property acquisitions included the Barossa Valley, which he populated with German Lutherans, and in which he built the town of Angaston. ${ }^{123}$ Angas Street in Adelaide is home to the High Court, Federal Court, and the South Australian Police (SAPOL) headquarters. Angas is not recorded by the Legacies database as having held slaves, nor to having obtained any meaningful benefit. ${ }^{124}$ However, his association with compensation totalling $£ 6,942$ in 1835 is that he 'collected' the claims or, as Hall explains, 'he was acting as an agent for slave-owners in London'.125 Angas's business involved slavery in its Honduran production line and was directly involved in the slave trade. ${ }^{126}$ This is despite the anti-slavery views Angas apparently held and which were trumpeted upon his demise. ${ }^{127}$ As we will see Angas was pivotal to South Australia's creation.

Raikes Currie was a banker and zealot in the United Kingdom who spied opportunities in a hypothetical new colony in southern Australia and played a significant role in the founding of the province. ${ }^{128} \mathrm{He}$ was a long serving member of the Commons and was heavily involved with his family bank, Curries \& Co. According to the Legacies database his father, Isaac Currie, was a mortgagee who, along with two others, was awarded on trust $£ 15,400$ in compensation in 1837 from the estate of Job Mathew Raikes; a relative who died in 1833 in debt to Curries \& Co. ${ }^{129}$ Raikes Currie's older brother was Isaac George Currie who was trustee of $£ 20,000$ in compensation.130 Raikes Currie's familial connections and his involvement in the family bank compromise his link to slavery. Currie appears to have been lost to history despite being honoured by Currie Street in Adelaide, named in his honour in the 1830s. Currie Street is home 
BEFORE I NOW

Vol. 1 No. 1

to the University of South Australia, Australia's third oldest tertiary education institution, as well as the SA branch of the Department of Foreign Affairs and Trade, TAFE, and the Adelaide Remand Centre. ${ }^{31}$ Currie had advocated in London for, and donated to, the establishment of the Church of England in Adelaide, along with Curries \& Co. ${ }^{132}$ Before the construction of what is now Holy Trinity Church on North Terrace, a temporary church was located at Currie Street. ${ }^{133}$ But his immediate family does not appear to have ever moved to Australia. His son, Baron Currie, was a senior bureaucrat in the United Kingdom who married the poet Violet Fane. ${ }^{134}$

Sir Anthony Musgrave was the Governor of South Australia from 1873 to 1877 and later served as governor of Queensland. ${ }^{135}$ His father, Anthony Snr., was a slaveholder in Antigua who was awarded $£ 260$ compensation for his 89 slaves. ${ }^{136}$ His uncles, William and Richard, were also slaveholders awarded compensation. ${ }^{137}$ So too was William Byam, his father-in-law through his first wife, who was a slaveholder in Antigua compensated $£ 4,100$ for his 256 slaves in 1835. 138 There is a Musgrave Street in Adelaide, a Musgrave Avenue in Lucindale, the Musgrave Ranges on the border of SA and the Northern Territory and the town of Arthurton on the Yorke Peninsula, named after his son. ${ }^{139}$ At the time of his death in 1888 he was said to have brought to Queensland his considerable knowledge of coffee and sugar planting. ${ }^{140}$

Another prominent South Australian with links to slavery was the Reverend Charles Marryat Jnr. He was influential in the Anglican Diocese of Adelaide, being archdeacon, dean and vicar general, as well as effectively operating as acting coadjutor bishop on a number of occasions. ${ }^{141}$ The first bishop of Adelaide, Augustus Short, was his uncle. He was particularly involved in the society church, Holy Trinity Church. ${ }^{142}$ He was eldest son to Charles Snr. who, along with his brother, was compensated some $£ 34,000$.143 Many of the slaves had been held by other people; but together they owned $923 . .^{144}$ Charles Snr. worked with Henry Barkly on business matters in Trinidad.145 Charles Snr.'s sister, Augusta Sophia Marryat, married the fifth Governor of South Australia, Sir Henry Young ${ }^{146}$ He would also serve as governor of Tasmania. The city of Port Augusta is named in Augusta's honour. ${ }^{147}$ Charles Jnr.'s son, Charles Howard, became a noted Adelaide architect who designed Urrbrae House, owned by the University of Adelaide. ${ }^{148}$ Governor Young was friends with David Melville, who was secretary of the Chamber of Commerce in Adelaide and had been compensated £9,400 in 1835 for the 188 slaves he had held in British Guiana. ${ }^{149}$

Jacob Montefiore was a merchant, financier and playwright who was influential in the early years of the South Australian colony, despite residing elsewhere..$^{150}$ Montefiore's Hill, upon which the statue of Colonel Light stands pointing over Adelaide, is named in his honour, as is Montefiore Road..$^{151} \mathrm{He}$ and his brother Joseph, who eventually lived in Adelaide, were trustees of $£ 386$ in compensation awarded to child beneficiaries, presumably of a diseased slaveholder who held 20 slaves. ${ }^{152}$ However, McQueen demonstrates that Eliezer Montefiore, their father, was a slaveholder of at least 211 slaves in the British West Indies at the turn of the nineteenth century. ${ }^{153}$

William Alexander Mackinnon was a member of the Commons who was involved in the creation of South Australia. In 1836 he appears to have been awarded some £2,300 in compensation arising from his slaveholding grandfather and father. ${ }^{154}$ Similarly, Sir Stephen Walcott was involved in the creation of South Australia. His father, Robert, was a slaveholder in Barbados who was awarded $£ 4,400$ for his 202 slaves in 1836.155 William John Peterswald was warden of the South Australian goldfields and commissioner of police, as well as a prominent member of Grand Lodge. ${ }^{156}$ His father, William Snr., was compensated some $£ 5,000$ for the 200 slaves he held in Jamaica. ${ }^{157}$ Other 
beneficiaries of slavery included those in the Stirling family. Archibald Stirling was the father of this prominent and influential South Australian family. He received some $£ 10,000$ in 1835 for over 460 slaves he held in Jamaica. ${ }^{158}$ Although Edward Snr., his son, was illegitimate he was the recipient of a gift of $£ 1,000$ in 1838 upon leaving for South Australia. ${ }^{159}$ He helped frame the first Constitution of South Australia, became a member of the Legislative Council and is honoured by the town of Stirling in the Adelaide Hills. ${ }^{160}$ He was also a founding member of what is now the agribusiness, Elders. His sons, Edward Charles and John Lancelot, were highly influential South Australians who married women from prominent families. ${ }^{161} \mathrm{~A}$ further beneficiary was James Wiles, a horticulturalist who was friends with Joseph Banks and Mathew Flinders, also a beneficiary of slavery ( $£ 1,657$ for 88 slaves) and honoured by Cape Wiles, Eyre Peninsula. ${ }^{162}$

Adam Lindsay Gordon was a South Australian politician, policeman, horseman and poet from Mount Gambier who also lived in Western Australia, Ballarat and Melbourne. ${ }^{163} \mathrm{He}$ is considered to be a highly influential Australian literary figure, especially for his collection Bush Ballads and Galloping Rhymes (1867). His house in Mount Gambier, Dingley Dell, is now a museum while Adam Lindsay Gordon Cottage in Ballarat, located in the botanic gardens, is used as a gift shop. ${ }^{164}$ Although he is not widely known at present he was tremendously famous in his time and is recognised by a bust in Poets' Corner, Westminster Abbey, London, and a statue at Spring Street, Melbourne. ${ }^{165}$ In 1859 he inherited $£ 7,000$ from his mother, Harriet, who had herself inherited money from a deceased relative connected to slavery. ${ }^{166}$ The poet Fidelia S. T. Hill, who lived in Adelaide from 1836 to 1838 and then Tasmania, was the first woman to publish poetry in Australia. ${ }^{167}$ In 1835 she was the beneficiary of $£ 136$ compensation awarded to her husband, Robert. ${ }^{168}$ Her two sisters were also beneficiaries. ${ }^{169}$

Another South Australian connected to slave money was Mary Bell Campbell. Legacies reports that Mary's mother, Mary Snr., left her daughter half of the unknown sum owed to her from 'negro labour' in Jamaica around 1825, as well as a quarter of the proceeds resulting from the sale of her entire estate, which included slaves. ${ }^{170}$ Mary married Envidale Savage Norman Campbell in 1832.171 After moving to Adelaide in 1849 Envidale was appointed to the Legislative

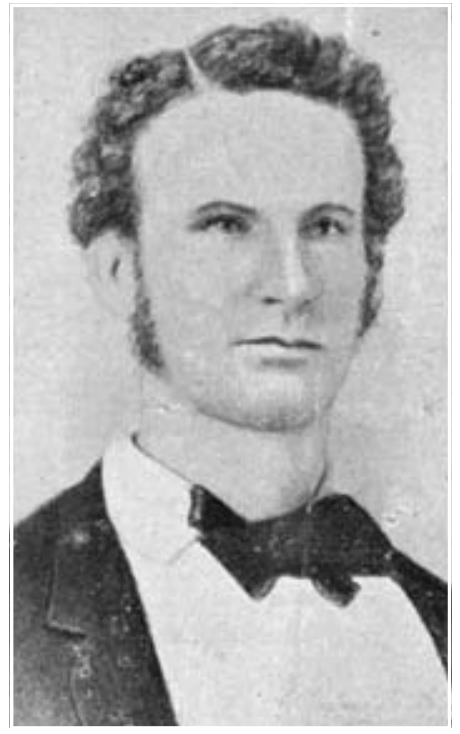

\section{Adam Lindsay Gordon}

Adam Lindsay Gordon Memorial Cottage marketing brochure, c1955. Federation University Historical Collection, 03646. Council in 1851, then private secretary to Governor Charles La Trobe in Victoria in 1852 and finally the first Registrar-General of Victoria in 1853; a position of power and importance. ${ }^{172}$ Although he was not nearly as prominent as other South Australian beneficiaries, John Knox Jr. was reported in the Advertiser at his death in 1908 to have been 'one of the pioneer businessmen of Adelaide'. ${ }^{173}$ His father, John Snr., was awarded most of $£ 589$ in compensation in 1836 for 22 slaves. ${ }^{174}$ There is evidence that John Snr. was a brutal slaveholder, with an instance reported in 1837 when a (presumably) former slave of his was revealed to have severe whip scars on his back that had become infected:

After the flogging master would not allow anybody to bathe my back, and the flies too it; if it had not been for strangers I would have been a dead man. [sic]. ${ }^{175}$

His mother, Rachael, was awarded $£ 731$ in compensation for 28 slaves in 1838.176 John Jnr. came to Adelaide with his father and brother, William, in 1837. According to one contemporary account of the travellers:

They are very respectable people, and I should say worth property - he has disposed of his Jamaican property, and he is going on his sons account to put them in some way of business... ${ }^{177}$ 
BEFORE I NOW

Vol. 1 No. 1

Other beneficiaries include the six children of John Samuel August who, in 1839, inherited the $£ 2,400$ compensation he received for his 40 slaves in $1835 .{ }^{178}$ The family moved East to Melbourne after their business ventures soured; his daughter married Alfred Langhorne in 1838 before they built Altona Homestead in $1842 .{ }^{179}$

\section{The creation of South Australia}

In light of the evidence available through the Legacies database, the history of South Australia's creation must be reconsidered. The section above demonstrates that the province had a strong link to British slavery, as did Victoria. However, the individuals implicated provoke this new line of enquiry. The historian Humphrey McQueen concludes that:

Not every bluestone in Adelaide is mortared with the blood of a slave as is charged against the bricks of Bristol and Liverpool, yet the fine particles that cemented the City of Light's Proclamation Tree were mixed with the blood of West Indian slaves and Kaurna bones, since plastered over with an insouciant scholarship. ${ }^{180}$

This conclusion is by no means hyperbolic. As McQueen identified, and as this article bolsters, South Australians cannot justifiably maintain that the state is Australia's only 'free-state'. Putting to one side the atrocities committed against Indigenous societies in order to secure the province, the role of slave money alone in its creation renders a fatal blow to the basis of this self-image. ${ }^{181}$ Considered together it can be said the reality of South Australia's free creation has died twice. But the spirit persists.

While founded by free persons of property without convict settlement and acting under the authority of the monarch, South Australia owes its existence to beneficiaries of British slavery. The importance of George Fife Angas and Raikes Currie stems from the South Australia Act of 1834. Various financial arrangements needed to be honoured before the Act could lawfully vest power for the province's creation. An essential condition was that 'none of the powers and authorities...given to his majesty' or anyone else would be valid until certain conditions were met. One of these conditions was the purchasing of $£ 20,000$ in 'exchequer bills or other government securities', while another required the sale of $£ 35,000$ in land. As stated by the Act, the United Kingdom did not want to consent to the establishment of the province if it was to disadvantage them financially.

To satisfy these demands Angas formed the South Australian Company, serving as its chairperson, with the intention of purchasing enough land to satisfy the Act. ${ }^{182}$ The list of directors include many names instantly recognisable to any reader familiar with Adelaide and South Australia: Currie, Charles Hindley, Henry Kingscote, John Pirie, John Rundle, and Henry Waymouth. 183 Directors were permitted to 'borrow or raise any sum or sums for the purpose of the said company' with an overall limit of $£ 50,000$, but had to buy $£ 2,500$ in shares as a minimum. ${ }^{184}$ Angas invested over $£ 40,000$ in shares to ensure these objectives were reached. ${ }^{185}$ Currie purchased $£ 5,000$ in shares, while his brother purchased $£ 2,600$ and another relative purchased $£ 1,500.186$ Under the deed of settlement there was provision for trustees to be appointed to oversee the purchase of Exchequer bills and securities. ${ }^{187}$ But the company's influence carried beyond its primary function. For example, South Australian banking arose from it in $18377^{188}$ So, beneficiaries of slavery contributed significant capital to the creation of the province in the 1830s.

The roles played by Angas and Currie may yet be proven to be of greater import. Currie's involvement appears to have arisen because of Angas. From at least 1829, Angas 
had a financial relationship with Curries \& Co ${ }^{189}$ The aforementioned contributions made by the Currie family, however, may be far less significant than another financial contribution made by the bank or Raikes Currie. He is reported to have provided in the range of $£ 10,000$ to $£ 30,000$ towards the establishment of the province through some kind of financial instrument, the nature of which is unclear. The amount could have been considerably higher. There may have been a loan of $£ 80,000$ or Currie may have acted as surety, either with respect to the required sale of $£ 35,000$ in real property or $£ 20,000$ in government securities..$^{190}$ Most sources state the amount of $£ 20,000$ as surety or trustee but it is possible that there exists a feedback loop of a kind whereby the contents of an article published in 1858 is repeated by inattentive journalists until 1954 .

The financial instrument, as reported by contemporary and subsequent newspapers, is referred to on the side of a silver bowl, held by the Adelaide City Council. It was gifted to that institution in 1858 by Raikes Currie, and three others, so that councillors may honour the memory of Colonel Light at the beginning of each year. ${ }^{191}$ This practise appears to have been undertaken until at least 1954. The inscription on the side of the bowl is reported to read as follows:

Presented to the Mayor and Corporation of Adelaide that they may thereout drink Australian wine to the memory of Lieut.-Col. Light [sic], the first Surveyor-General of South Australia, by some of the original founders of the Colony, viz., George Palmer, Esq., Jacob Montefiore, Esq., two of the original commissioners appointed by His Majesty William IV in 1835 , who raised the first $£ 35,000$ by sale of land and $£ 18,000$ by Ioan; Raikes Currie, Esq., M.P. for Northampton, the trustee for $£ 20,000$ of the above $£ 35,000$ required by Parliament to be deposited to obviate the attempt to found the Colony of South Australia causing any charge to England; Alexander Elder, Esq., of Lancing in Sussex. ${ }^{192}$ (Emphasis added).

This description may not be accurate, if it even exists. ${ }^{193}$ Certainly, the impression it creates is that Palmer, Montefiore, Currie and Elder were solely responsible for founding South Australia. At the very least it was plainly intended to celebrate the quadrumvirate by way of the deceased colonel.

Decades later the first premier of South Australia, Boyle Travers Finniss, seems to have contested this grandiose description in 1883. However, his intervention further implicates Curries \& Co. in the creation of South Australia:

The chairman [Colonel Torrens] appeared in the boardroom... [and] announced that "South Australia was no more"... I do not remember, nor should I care to record on this occasion all the circumstances stated by Colonel Torrens. This statement was a serious blow and discouragement to those who had left professions and broken up establishments to join in forwarding the new settlement. Amongst the difficulties stated it was found that the whole sum of $£ 35,000$ had not been subscribed for land orders, and a day had been fixed before which if not realised the undertaking was to be abandoned. It was stated that this point could be settled if six intending settlers of reputed means would sign a bond for $£ 10,000$ in favour of Raikes, Currie, \& Co., the eminent London bankers, as a guarantee to cover their risk if they advanced the balance required to complete the land fund. Mr. John Brown was the principle negotiator in this transaction, and the bond was signed by Mr. John Morphett, Mr. George Strickland Kingston, Mr. John Brown, Dr. [Edward] Wright, Mr. Boyle Travers Finniss, and I believe Mr. Osmond Gilles. Before the appointed time, however, the land fund was completed, and other arrangements also having been settled the expedition was allowed to start... ${ }^{194}$ 
BEFORE / NOW

Vol. 1 No. 1

If this is correct, the agreement with Curries \& Co. was not acted upon. It is not clear if this agreement was ancillary to an amount provided by Raikes Currie. Certainly, further prominent South Australians are implicated in the web of slavery through their pursuit of capital held by the Currie family, and doing so after abolition and emancipation.

According to A History of South Australia, the financial obligations of the Act were met by the colonists. ${ }^{195}$ If Finniss was correct then the quadrumvirate (Palmer, Montefiore, Currie and Elder) were wrong. Finniss was a senior politician and also a member of the Old Colonists' Association. ${ }^{196}$ But his role in the establishment of the province was minor compared to the roles of Currie and Montefiore. While the former's name is not mentioned in the second (1838), third (1839) and fourth (1840) Annual Report[s] of the Colonization Commissioners for South Australia, the selection of his name for one of Adelaide's most prominent streets indicates he played an important role at some stage. Further research is required to determine if Currie or the Currie family invested more than the aforementioned $£ 9,000$ in shares and the importance of this intervention, if it was ever executed.

\section{Public honours, place-names and anti-racism}

Beyond the questions of moral integrity, especially with respect to self-image, and the oversight in history writing, there remains the question of public honours. The law as it presently stands in South Australia and Victoria clearly intends place-names to serve as public honours. In South Australia, placenames are governed by the Geographical Names Act 1991 and the Local Government Act 1999. The planning minister or delegated authority has the power to change the name of any public place (or historic or geographical feature), with the exception of streets and roads. ${ }^{197}$ The Geographical Names Guidelines set out a series of mostly practical considerations about name changes, although the Surveyor-General does consider popularity of a suggested name change. ${ }^{198}$ The Adelaide City Council's Road Naming Policy provides that road names must be named for people of historical significance and, in the case of major roads, 'prominent and worthy citizens who have contributed to the betterment of the community'.199 It also allows for a change to occur if it 'is deemed in the public interest'. The Model Policy for the Selection of Road Names, issued by the State government, goes further by providing that road names cannot be 'offensive or likely to give offence' or 'incongruous - out of place'. ${ }^{200}$ In Victoria, the law around placename changes is clearer still. The Geographical Place Names Act 1998 requires the enforcement of the 2016 guidelines, which provide the power of placename renaming to the planning minister or the Registrar of Geographical Names. ${ }^{201}$ The authority 'must... consider' whether the person 'should be or have been held in strong regard by the community', and 'should consider the person's achievements, [and] relevant history' ${ }^{202}$ In the present time, there is no question that slavery was (and is) immoral. It remains to be seen if public honours will be maintained for beneficiaries of slavery, in light of the gradual removal of place-names honouring people who committed other atrocities, like John Batman. ${ }^{203}$ It must be considered that beneficiaries of slavery had been engaged in a practice considered immoral at the time and, as with perpetrators of child abuse in the present time, public honours reflect support of a morally reprehensible act. Changing place-names is not a superficial act; it is part of a broader realisation of anti-racism, seemingly ubiquitous at present. Anti-racism cannot coexist with narratives of the past that overlook links to slavery or, indeed, other atrocities. ${ }^{204}$ 


\section{Conclusion}

The Legacies database has made a major contribution to our understanding of the British Empire and Australian history. Using the evidence of the database, it is demonstrable that beneficiaries of slavery were present in Victoria and South Australia. Many of these people achieved positions of power and influence, contributing significant capital and talent, much of which is still displayed some one hundred and fifty years later. In the case of South Australia it is evident that the actions of beneficiaries of slavery were consequential, although the precise amount of capital invested in the province's creation remains unknown. This is just one example of the influence beneficiaries of slavery exerted in the empire, especially after emancipation when slaves were converted to token money. Given the many public honours awarded to these people, especially in the form of place-names, the influence can be said to have been considerable. Further research will most certainly show that this was not unique to Victoria and South Australia but all of the former colonies that now comprise Australia. The faint rattle of chains can be heard in many parts of the former British Empire, one need only pause to listen. Further research is also required to ascertain the additional amount contributed by Raikes Currie, as well as the relationship between the founders and Curries \& Co. bank. Another important line of future enquiry is the degree of influence beneficiaries held over colonial society, including discourses on slavery and economics. Yet, another line of enquiry is to ask, what presence did former slaves have in these colonies? For example, the former slave John Joseph had been one of the 13 people tried for treason after the Eureka Rebellion. ${ }^{205}$ Nevertheless, it can be said there is yet another scar on the gnarled face of Australian History.

\section{CJ Coventry | PhD candidate}

\section{CRCAH, Federation University Australia}

Email: cameroncoventry@students.federation.edu.au

Cameron James Coventry is a PhD candidate at CRCAH. He was raised in the town of Stirling in the Adelaide Hills, South Australia, which is named after Edward Stirling. He is married to Rebecca Coventry, a descendent of Barossa Valley Lutherans, who grew up near Angaston, South Australia, which is named after George Fife Angas.

Cameron Coventry is a PhD candidate at Federation University Australia and is in receipt of an Australian Government RTP Stipend Scholarship.

\section{Notes}

1 Cf. Catherine Hall, "Writing History, Making 'Race': Slave-owners and their stories," Australian Historical Studies 47(3) (2016): 368; Catherine Hall, "Troubling Memories: Nineteenth-century histories of the slave trade and slavery," Royal Historical Society 21 (2011): 152.

2 Hall, "Writing History, Making 'Race'," 368.

3 Ibid.

4 Paul Daley, "Colonial Australia's foundation is stained with the profits of British slavery," Guardian, 21 September 2018, https://www.theguardian.com/world/2018/sep/21/ colonial-australias-foundation-is-stained-with-the-profitsof-british-slavery; Clinton Fernandes, Island Off the Coast of Asia: Instruments of statecraft in Australian foreign policy (Monash University Press: Melbourne, 2018), 1216; Humphrey McQueen, "Born Free: Wage-slaves and -slaves," in Carolyn Collins \& Paul Sendziuk, eds. Foundational Fictions in South Australian History (Adelaide: Wakefield Press, 2018), 43-63.
5 Hall, “Writing History, Making 'Race,", 366.

6 Noam Chomsky, Power Systems (London: Penguin Books, 2013), 97; George Orwell, Nineteen Eighty-Four (London: Penguin Books, 2011), 39-40.

7 Hall, "Troubling Memories," 151.

8 Catherine Hall, "Doing Reparatory History: bringing 'race' and slavery home," Race \& Class 60(1) (2018): 4-5.

9 Hall, "Writing History, Making 'Race'," 369.

10 Ibid., 367.

11 Hall, "Doing Reparatory History," 12.

12 Weingast, "Persistent Inefficiency," 17-18, 24.

13 Claudius K. Fergus, Revolutionary Emancipation: Slavery and abolitionism in the British West Indies (Baton Rouge: Louisiana State University Press, 2013), 29. 
14 Kenneth Morgan, Slavery and the British Empire: From Africa to America (Oxford: Oxford University Press, 2007), 7-9, 34-35.

15 Ibid., 12.

16 Ibid.

17 Ibid., 47

18 Ibid., 17-18.

19 Ibid., 36

20 Barry R. Weingast, "Persistent Inefficiency: Adam Smith's theory of the persistence of slavery and its abolition in Western Europe," Social Science Research Network (2016): 4-6; Morgan, Slavery and the British Empire, 150; Christopher Hitchens, "How Paine's 'Rights of Man' Changed the World," National Public Radio, 23 October 2007, https://www.npr.org/2007/10/23/15328527/hitchenshow-paines-rights-changed-the-world; Martin Luther King (speech, delivered 26 February 1965 at Temple Israel of Hollywood); Quote Investigator, "The arc of the moral universe is long, but it bends toward justice," 15 November 2012, https://quoteinvestigator.com/2012/ 11/15/arc-of-universe/.

21 e.g. Morgan, Slavery and the British Empire, 169-171; Trevor Burnard \& Kit Candlin, "Sir John Gladstone and the debate over the amelioration of slavery in the British West Indies in the 1820s," Journal of British Studies 52 (2018), 760-761, 764, 779; Fergus, Revolutionary Emancipation, 37, 57, 70-72; Hall, "Troubling Memories," 152.

22 Fergus, Revolutionary Emancipation, 60, 63, 176; Weingast, "Persistent Inefficiency," 4-6; Karl Polanyi, The Great Transformation: The political and economic origins of our time (Beacon: Boston, 2001), 84; P. X. Scanlan, "Blood, Money, and Endless Paper: Slavery and capital in British imperial history," History Compass 14(5) (2016), 219.

23 Morgan, Slavery and the British Empire, 169-171; Fergus, Revolutionary Emancipation, 147-148, 180-181.

24 Morgan, Slavery and the British Empire, 176, 193; Fergus, Revolutionary Emancipation, 24, 142.

25 Burnard \& Candlin, "Sir John Gladstone," 762-763, 765, 774, 776; Fergus, Revolutionary Emancipation, 40, 44, 159, 177.

26 Fergus, Revolutionary Emancipation, 64.

27 Morgan, Slavery and the British Empire, 185-186, 188-190.

28 Ibid., 182.

29 Morgan, Slavery and the British Empire, 182; Hall, "Troubling Memories," 147.

30 Weingast, "Persistent Inefficiency," 2, 6-7; Morgan, Slavery and the British Empire, 50, 190-192.

31 Morgan, Slavery and the British Empire, 194-197.

32 Morgan, Slavery and the British Empire, 199; Peter R. Mitchell \& John Schoeffel, eds., Understanding Power: The indispensable Chomsky (Scribe Publications: Melbourne, 2002), 361; Hall, "Writing History, Making 'Race'," 369, 379; Scanlan, "Blood, Money, and Endless Paper," 222.

33 Hall, “Writing History, Making 'Race'," 366-367.
34 Ibid., 369, 373.

35 Ibid., 367.

36 Geoffrey Blainey, A History of Victoria (Cambridge University Press: Cambridge, 2013), 20-23, 28.

37 Ibid., 29.

38 Ibid., 41-43.

39 Ibid., 53, 57.

40 B. A. Knox, "Barkly, Sir Henry (1815-1898)," Australian Dictionary of Biography (Melbourne University Press: Melbourne, 1969), http://adb.anu.edu.au/biography/barkly-sir-henry-2936.

41 Ibid.

42 Knox, "Barkly, Sir Henry,"; Legacies of British Slave-ownership, "Henry Barkly," accessed 30 November 2018, https://www.ucl.ac.uk/lbs/person/view/10612.

43 Legacies of British Slave-ownership, "Aeneas Barkly" University College London, accessed 30 November 2018, https://www.ucl.ac.uk/lbs/person/view/28744.

44 Barkleys Bank archive, "Colonial Bank," accessed 3 December 2018, https://www.archive.barclays.com/items/ show/5336.; Legacies of British Slave-ownership, "Aeneas Barkly: Commercial legacy details," University College London, accessed 3 December 2018, https://www.ucl.ac.uk/lbs/commercial/view/1597579505.

45 Legacies of British Slave-ownership, "Henry Barkly."

46 Legacies of British Slave-ownership, "Aeneas Barkly."; Letter from Herbett Jarertt James to Mrs. Millward, 18 May 1829; Letter from Herbett Jarrett James to Colin McKenzie Esq. 22 July 1828; Letter from Herbett Jarret James to Sir Michael B. Clare of Davidson Barkley \& Co. London, 18 October 1831.

47 Legacies of British Slave-ownership, "Davidsons, Barkly \& Co." University College London, accessed 3 December 2018, https://www.ucl.ac.uk/lbs/firm/view/-496653648; Nick Hide, "The Remarkable Barkly Family - and their Kirkmichael Origins," Kirkmichael Trust, accessed 3 December 2018, http://www.kirkmichael.info/BarklyEnclosure.html.

48 Guyana Times International, "Journey to Highbury," 4 May 2018, https://www.guyanatimesinternational.com $/ ? \mathrm{p}=45816$

49 St Kilda Historical Society, "Barkly Street," accessed 30 November 2018, http://www.stkildahistory.org.au/research-resources/streets-buildings/streets/barkly-street.

50 Department of Natural Resources and Mines (Qld.), s. v. "Barkly Tableland," accessed 30 November 2018, https://wuw.dnrm.qld.gov.au/qld/environment/land/placenames/search\#/search=Barkly_Tableland\&types=0\&place= Barkly_Tableland1654

51 Australian Plant Name Index, s.v. "Barklya," https://biodiversity.org.au/nsl/services/apni?name=Barklya+syringifolia\&max=100\&display=apni\&search=true; Brisbane Rainforest Action \& Information Network, "Barklya syringifolia," accessed 3 December 2018, http://www.brisrain.org.au/ 01_cms/details_pop.asp?ID=39; Hide, "The Remarkable Barkly Family." 
52 F. K. Crowley, "Darling, Charles Henry (1809-1870)," Australian Dictionary of Biography (Melbourne University Press: Melbourne, 1972), http://adb.anu.edu.au/biography/darling-sir-charles-henry-3367/text5085.

53 Legacies of British Slave-ownership, "Ann[e] Wilhelmina Darling (nee Dalzell)," University College London, accessed 17 December 2018, https://www.ucl.ac.uk/lbs/person/ view/2146652311.

54 Legacies of British Slave-ownership, "William Lindsay Darling," University College London, accessed 17 December 2018, https://www.ucl.ac.uk/lbs/person/view/9903.

55 Umberto Quattrocchi, CRC World Dictionary of Medicinal and Poisonous Plants: Common names, scientific names, eponyms, synonyms and etymology (CRC Press: Boca Raton, 2012), 1332.

56 Victorian Heritage Database, "Darling Gardens," accessed 17 December 2018, https://vhd.heritagecouncil.vic.gov.au/ places/101627/download-report.

57 Argus, "The Late Sir Edward Eyre Williams," 6 May 1880, 6 (Trove).; Patrick Street, "Edward Eyre Williams (1813-1880) Judge of the Supreme Court of Victoria," 1.

58 Street, "Edward Eyre Williams," 2.

59 Robert Miller, "Williams, Sir Edwards Eyre (1813-1880)," Australian Dictionary of Biography (Melbourne University Press: Melbourne, 1976), http://adb.anu.edu.au/biography/williams-sir-edward-eyre-4855; "Statistical Register of the State of Victoria for the Year 1907," Parliament of Victoria, accessed 30 November 2018, https://www.parliament.vic.gov.au/papers/govpub/VPARL1908No10.pdf.

60 "Our history," Supreme Court of Victoria, accessed 30 November 2018, https://www.supremecourt.vic.gov.au/ about-the-court/our-history

61 Street, "Edward Eyre Williams," 3; Miller, "Williams, Sir Edwards Eyre."; "The History of Como House," National Trust, accessed 30 November 2018, https://www.nationaltrust.org.au/places/como-house-and-garden/; City of Stonnington, "Heritage Citation Report," 2013, accessed 30 November 2018, https://www.stonnington vic.gov.au/files/assets/public/adl/heritage-overlays/ho44339-41-kensington-road-south-yarra.pdf.

62 Royal Melbourne Hospital Act 1935 (Vic), preamble.

63 Legacies of British Slave-ownership, "Edward Eyre Williams," University College London, accessed 17 December 2018, https://www.ucl.ac.uk/lbs/person/view/44601.

64 Legacies of British Slave-ownership, "Robert Gwilt," University College London, accessed 17 December 2018, https://www.ucl.ac.uk/lbs/person/view/29571.

65 "Sir Edward E. Williams, 1813-1880," National Portrait Gallery, accessed 30 November 2018, https://www.portrait.gov.au/people/edward-eyre-williams-1813.

66 Robert Miller, "Williams, Sir Hartley (1843-1929)," Australian Dictionary of Biography (Melbourne: Melbourne University Press, 1976), http://adb.anu.edu.au/biography/williamssir-hartley-4856; Argus, "The Late Sir Edward Eyre Williams."; Patrick Steel, "Sire Hartley Williams (18431929) Judge of the Supreme Court of Victoria," 3-5; Brisbane Courier, "Sir Hartley Williams," 16 July 1929, 15.
67 National Trust Database, s.v. "Flete," accessed 30 November 2018, http://vhd.heritage.vic.gov.au/search/nattrust_result_detail/66556; "Sir Hartley Williams 19431929," National Portrait Gallery, accessed 3 December 2019, https://www.portrait.gov.au/people/hartley-williams1843.

68 Henry Rosenbloom, "Carter, Godfrey Downes (18301902)," Australian Dictionary of Biography (Melbourne University Press: Melbourne, 1969), http://adb.anu.edu.au/ biography/carter-godfrey-downes-3174.

69 Rosenbloom,"Carter, Godfrey Downes."; David Tolmie Merrett, "The Australian Banking Crashes of the 1890s Revisited," Business History Review 87 (2013): 409.

70 Legacies of British Slave-ownership, "Jamaica St Ann 931," University College London, accessed 3 December 2018, https://uww.ucl.ac.uk/lbs/claim/view/11877; Legacies of British Slave-ownership, "Jamaica St Mary 399," University College London, accessed 3 December 2018, https://www.ucl.ac.uk/lbs/claim/view/18280 Cf. Fernandes, Island Off the Coast of Asia, 14.

71 Legacies of British Slave-ownership, "John Adams Carter," University College London, accessed 3 December 2018, https://www.ucl.ac.uk/lbs/person/view/11877.

72 Legacies of British Slave-ownership, "Jamaica St Ann 166," University College London, accessed 3 December 2018, https://www.ucl.ac.uk/lbs/claim/view/18672; Legacies of British Slave-ownership, "Dorothy Simes Carter," University College London, accessed 3 December 2018, https://www.ucl.ac.uk/lbs/person/view/18672.

73 Frank Strahan, "Graham, James (1819-1898)," Australian Dictionary of Biography (Melbourne University Press: Melbourne, 1972), http://adb.anu.edu.au/biography/graham-james-3650/text5689.

74 Legacies of British Slave-ownership, "Barbados 4364," University College London, accessed 3 December 2018, https://www.ucl.ac.uk/lbs/claim/view/6781.

75 CE Sayers, "Windsor, Arthur Lloyd (1833-1913)," Australian Dictionary of Biography (Melbourne University Press: Melbourne, 1976), http://adb.anu.edu.au/biography/windsor-arthur-lloyd-4872.; Geelong Advertiser, "Personal," 22 January 1913, 3 (Trove).

76 Observer (Adelaide), "Mr. A Lloyd Windsor," 1 February 1913, 39 (Trove).

77 Legacies of British Slave-ownership, "Henry George Windsor," University College London, accessed 4 December 2018, https://www.ucl.ac.uk/lbs/person/view/6068.

78 Sayers, "Windsor, Arthur Lloyd."

79 Legacies of British Slave-ownership, "Hon. Alexander Murray of Frimley Surrey," University College London, accessed 17 December 2018, https://www.ucl.ac.uk/lbs/person/view/2146003034.

80 J. Ann Hone, "Bright, Charles Edward (1829-1915)," Australian Dictionary of Biography (Melbourne University Press: Melbourne, 1969), http://adb.anu.edu.au/biography/bright-charles-edward-149; Jennifer Turnbull, "Canterbury, third Viscount (1814-1877)," Australian Dictionary of Biography (Melbourne University Press: Melbourne, 1969), http://adb.anu.edu.au/biography/canterbury-thirdviscount-3161. 
81 Anthony Knight, "History," Beleura, accessed 13 December 2018, https://www.beleura.org.au/history/.

82 Millicent Weber, "A fortune built on slavery: the Bright Family Papers and their journey from UK to Melbourne," Conversation, 22 August 2016, http://theconversation.com/ a-fortune-built-on-slavery-the-bright-family-papers-andtheir-journey-from-uk-to-melbourne-58423.

83 Legacies of British Slave-ownership, "Robert Bright," University College London, accessed 13 December 2018, https://www.ucl.ac.uk/lbs/person/view/41207.

84 Weber, "A fortune built on slavery."; University of Melbourne Archives, s. v. "Bright Family Papers," accessed 13 December 2018, https://digitised-collections.unimelb. edu.au/ handle/11343/92255.

85 Geoffrey Serle, "Ebden, Charles Hotson (1811-1867)," Australian Dictionary of Biography (Melbourne: Melbourne University Press, 1969), http://adb.anu.edu.au/biography/ ebden-charles-hotson-2018/text2479; Blainey, A History of Victoria, 24, 29

86 Only Melbourne, s. v. "Black Rock House," accessed 13 December 2018, https://www.onlymelbourne.com.au/ black-rock-house\#.XBGsYydS uQ.

87 Friends of Black Rock House, "History," accessed 13 December 2018, http://www.blackrockhouse.org.au/ index.php/about-us/history.

88 Legacies of British Slave-ownership, "John Bardwell Ebden," University College London, accessed 13 December 2018, https://www.ucl.ac.uk/lbs/person/view/2146018570.

89 L. Arkley, "Sievwright, Charles Wightman (1800-1855)," Australian Dictionary of Biography (Melbourne University Press: Melbourne, 2005), http://adb.anu.edu.au/biography/sievwright-charles-wightman-13194/text23887.

90 Legacies of British Slave-ownership, "Tobago 46 (Concordia)," University College London, accessed 12 March 2019, https://www.ucl.ac.uk/lbs/claim/view/27706.

91 Legacies of British Slave-ownership, "Antigua 37 (Friar's Hill)," University College London, accessed 13 December 2018, https://www.ucl.ac.uk/lbs/claim/view/140.

92 Legacies of British Slave-ownership, "Nicholas Russell Garner," University College London, accessed 13 December 2018, https://www.ucl.ac.uk/lbs/person/view/1295813082

93 Legacies of British Slave-ownership, "Barbados 2870 (Vineyard)," University College London, accessed 13 December 2018, https://www.ucl.ac.uk/lbs/claim/view/4516

94 Philip Mennell, "Garner, Arthur," The Dictionary of Australasian Biography (Hutchinson \& Co.: London, 1892), https://en.wikisource.org/wiki/The_Dictionary_of_Australasian_Biography/Garner,_Arthur.

95 Legacies of British Slave-ownership, "Thomas Kingston the younger," University College London, accessed 13 December 2018, https://www.ucl.ac.uk/lbs/person/ view/44502

96 Legacies of British Slave-ownership, "Captain Duncan Graham," University College London, accessed 13 December 2018, https://www.ucl.ac.uk/lbs/person/view/42057.

97 Legacies of British Slave-ownership, "John Hylton," University College London, accessed 13 December 2018, https://www.ucl.ac.uk/lbs/person/view/23736.
98 Legacies of British Slave-ownership, "Francis Robertson Wallen," University College London, accessed 13 December 2018, https://www.ucl.ac.uk/lbs/person/view/29483; AR Hall, "Wallen, Robert Elias (1831-1893)," Australian Dictionary of Biography (Melbourne University Press: Melbourne, 1976), http://adb.anu.edu.au/biography/wallenrobert-elias-4793.

99 Legacies of British Slave-ownership, "William Chrystie," University College London, accessed 17 December 2018, https://www.ucl.ac.uk/lbs/person/view/46082.

100 Legacies of British Slave-ownership, "Tobago 12 (Sherwood Park)," University College London, accessed 4 December 2018, https://www.ucl.ac.uk/lbs/claim/view/27819.

101 Ibid.

102 Legacies of British Slave-ownership, "Celia Scott (nee King)," University College London, accessed 4 December 2018, https://www.ucl.ac.uk/lbs/person/view/46768.

103 Buninyong and District Historical Society Inc., "October 2004 Newsletter," accessed 4 December 2018, http://home.vicnet.net.au/ buninhis/pages/newoct04.htm.

104 Buninyong and District Historical Society Inc., "October 2004 Newsletter."; National Trust Database, s.v. "Mt Boninyong Homestead," accessed 4 December 2018, http://vhd.heritage.vic.gov.au/search/nt_search?nspn=Mt+ Boninyong+Homestead.

105 Pastoral Review, "Fleming, John King (1837-1916)," Australian Dictionary of Biography (Australian National University: Canberra, 2018), http://oa.anu.edu.au/ obituary/fleming-john-king-389/text390.

106 Legacies of British Slave-ownership, "John Park Fleming," University College London, accessed 17 December 2018, https://www.ucl.ac.uk/lbs/person/view/46769; Legacies of British Slave-ownership, "Maria Fleming," University College London, accessed 17 December 2018, https://www.ucl.ac.uk/lbs/person/view/46766.

107 Legacies of British Slave-ownership, "William Shiell of Homebush," University College London, accessed 4 December 2018, https://www.ucl.ac.uk/lbs/person/view/ 2146630377

108 Legacies of British Slave-ownership, "Queely Shiell," accessed 4 December 2018, https://www.ucl.ac.uk/lbs/person/view/25035.

109 Legacies of British Slave-ownership, "Queely Shiell."; Legacies of British Slave-ownership, "John Shiell," University College London, accessed 4 December 2018, https://www.ucl.ac.uk/lbs/person/view/386.

110 Legacies of British Slave-ownership, "William Shiell," University College London, accessed 4 December 2018, https://www.ucl.ac.uk/lbs/person/view/25088.

111 Legacies of British Slave-ownership, "Montserrat 111," University College London, accessed 4 December 2018, https://www.ucl.ac.uk/lbs/claim/view/24897.

112 Legacies of British Slave-ownership, "John Gregory," University College London, accessed 17 December 2018, https://www.ucl.ac.uk/lbs/person/view/195253126.

113 Hall, "Writing History, Making 'Race'," 374.

114 Ibid., 376-377. 
115 J. V. Barry, The Life and Death of John Price: A study of the exercise of naked power (Melbourne University Press: Melbourne, 1964), 74-75, 77-78, 84; Nell Musgrove, The Scars Remain: A long history of forgotten Australians and children's institutions (Australian Scholarly: Melbourne, 2013), 108

116 See Leigh Edmonds, "The Gaol on the Hill: The prelude to and construction of Bendigo's sandstone gaol," Before/Now 1 (2019), 47.

117 Barry, The Life and Death of John Price, 77, 107-108; e.g. Jenna Pandell, "Prisoners exploited for labour but they think it's a fair cop, guv," Conversation, 10 July 2014, https://theconversation.com/prisoners-exploited-forlabour-but-they-think-its-a-fair-cop-guv-28538; e.g. Shuba Krishnan, "The Northern Territory $\$ 20$ million prison workforce business," Australian Broadcasting Corporation, 21 February 2016, https://www.abc.net.au/news/201602-21/the-business-behind-bars-alice-springs/7183966; e.g. Economist, "Prison labour is a billion-dollar industry, with uncertain returns for inmates," 16 May 2017, https://www.economist.com/united-states/2017/03/16/ prison-labour-is-a-billion-dollar-industry-with-uncertainreturns-for-inmates.

118 Paul Sendziuk \& Robert Foster, A History of South Australia (Cambridge University Press: Cambridge, 2018), 10-11.

119 Ibid., 12-13.

120 Ibid., 12.

121 Ibid., 13.

122 Australian Dictionary of Biography, "Angas, George Fife (1789-1879)," (Melbourne University Press: Melbourne, 1966), http://adb.anu.edu.au/biography/angas-georgefife-1707.

123 Australian Dictionary of Biography, "Angas, George Fife"; Advertiser, "George Fife Angas."

124 Cf. Fernandes, Island Off the Coast, 13-14; Daley, "Colonial Australia's foundation."

125 Legacies of British Slave-ownership, "George Fife Angas," University College London, accessed 4 December 2018, https://www.ucl.ac.uk/lbs/person/view/-2109028293; Hall, “Writing History, Making 'Race'," 375.

126 McQueen, "Born Free," 59.

127 Advertiser, "George Fife Angas," 19 October 1909, 7. (Trove).

128 Royal Bank of Scotland, "Raikes Currie," accessed 5 December 2018, https://www.rbs.com/heritage/people/ raikes-currie-.html.; John Powell, "Currie, Raikes (18011881)," Oxford Dictionary of National Biography, accessed 5 December 2018, http://www.oxforddnb.com/ abstract/10.1093/ref:odnb/9780198614128.001.0001/odnb9780198614128-e-48015?rskey=PhOwgt\&result=1.

129 Legacies of British Slave-ownership, "Isaac Currie," University College London, accessed 5 December 2018, https://www.ucl.ac.uk/lbs/person/view/14445. Royal Bank of Scotland, "papers re estate of Nathaniel Bayly, West Indian plantation owner, 1780-1827," accessed 5 December 2018, https://www.rbs.com/heritage/companies/curries-and-co.html.
130 Legacies of British Slave-ownership, "Isaac George Currie," University College London, accessed 5 December 2018, https://www.ucl.ac.uk/lbs/person/view/43760.

131 Advertiser, "Adelaide in 1839," 1 January 1932, 6. (Trove).

132 Register News-Pictorial, "Street Corner History No. 14: Currie Street," 4 September 1929, 5. (Trove); South Australian Gazette and Colonial Register, "Episcopal Church," 12 August 1837, 3. (Trove); South Australian Gazette and Colonial Register, 18 June 1836, 1. (Trove).

133 Register News-Pictorial, "Street Corner History."

134 Daily Telegraph (Sydney), "Sir Philip Currie," 12 December 1895, 5. (Trove); Who's Who (UK), s. v. "Philip Currie," accessed 7 December 2018, http://www. ukwhoswho.com/ view/10.1093/ww/9780199540891. 001.0001/ww-9780199540884-e-185161; Daily Mercury (Qld), "Obituary," 15 May 1906, 3. (Trove).

135 H. J. Gibbney, "Musgrave, Sir Anthony (1828-1888)," Australian Dictionary of Biography (Melbourne University Press: Melbourne, 1974), http://adb.anu.edu.au/biography/musgrave-sir-anthony-4283.

136 Legacies of British Slave-ownership, "William Musgrave," University College London, accessed 6 December 2018.,

137 Legacies of British Slave-ownership, "William Musgrave," University College London, accessed 6 December 2018, https://www.ucl.ac.uk/lbs/person/view/44908; Legacies of British Slave-ownership, "Richard Musgrave," University College London, accessed 6 December 2018, https://www.ucl.ac.uk/lbs/person/view/1317.

138 Brisbane Courier, "Death of Sir Anthony Musgrave," 10 October 1888, 5. (Trove); Kent M. Haworth, "Musgrave, Sir Anthony," Canadian Dictionary of Biography (University of Toronto, 2003), http://www.biographi.ca/en/bio/musgrave_anthony_11E.html; Legacies of British Slave-ownership, "Sir William Byam Bart. Of Cedar Hill," University College London, accessed 6 December 2018, https://www.ucl.ac.uk/lbs/person/view/276.

139 Australia For Everyone, "The Names of South Australia: South Australia's regional cities and towns," accessed 6 December 2018, http://wnw.australiaforeveryone.com.au/ adelaide/names-sa.html.

140 Brisbane Courier, "Death of Sir Anthony Musgrave."

141 T. T. Reed, "Marryat, Charles (1827-1906)," Australian Dictionary of Biography (Melbourne University Press: Melbourne, 1986), http://adb.anu.edu.au/biography/marryat-charles-7497; Robert Edwards, "Howard, Charles Beaumont (1807-1843)," Australian Dictionary of Biography (Melbourne University Press: Melbourne, 1966), http://adb.anu.edu.au/biography/howard-charles-beaumont-2203; Hall, “Writing History, Making 'Race'," 370.

142 Reed, "Marryat, Charles."

143 Legacies of British Slave-ownership, "Charles Marryat," University College London, accessed 5 December 2018, https://www.ucl.ac.uk/lbs/person/view/42069.

144 Ibid.

145 Williams A. Green, British Slave Emancipation: The sugar colonies and the Great Experiment, 1830-1865 (Oxford University Press: Oxford, 1976), 215. 
146 H.J. Gibbney, "Young, Sir Henry Edward Fox (1803-1870)," Australian Dictionary of Biography (Melbourne University Press: Melbourne, 1976), http://adb.anu.edu.au/biography/young-sir-henry-edward-fox-4902; Legacies of British Slave-ownership, "Sir Henry Edward Fox Young," University College London, accessed 5 December 2018, https://www. ucl.ac.uk/lbs/person/view/2146630357; Hall, "Writing History, Making 'Race'," 370.

147 Port Augusta City Council, "Port Augusta Heritage Survey 2009," accessed 5 December 2018, https://data.environment.sa.gov.au/Content/heritage-surveys/2-PortAugusta-Local-Heritage-Review-2009.pdf.

148 Architects database, s. v. "Charles Howard Marryat", University of South Australia, accessed 5 December 2018, http://www.architectsdatabase.unisa.edu.au/arch_ full.asp?Arch_ID=136; University of Adelaide, "The History of Urrbrae House," accessed 13 December 2018, https://www.adelaide.edu.au/waite-historic/urrbraehouse/history/

149 Legacies of British Slave-ownership, "David Melville," University College London, accessed 5 December 2018, https://www.ucl.ac.uk/lbs/person/view/45339.

150 Legacies of British Slave-ownership, “Jacob Montefiore," University College London, accessed 5 December 2018, https://www.ucl.ac.uk/lbs/person/view/3235; Martha Rutledge, "Montefoire, Jacob Levi (1819-1885)," Australian Dictionary of Biography (Melbourne University Press: Melbourne, 1974), http://adb.anu.edu.au/biography/montefiore-jacob-levi-4225.

151 Jude Elton, "Montefiore Hill," History Trust of South Australia, accessed 5 December 2018, http://sahistoryhub.com.au/places/montefiore-hill; Peter Bramble, "Turbulent Christening of Adelaide's Streets: When Colonel Light was pushed aside," Advertiser, 5 June 1937, 24.

152 Legacies of British Slave-ownership, "Barbados 1274," University College London, accessed 5 December 2018, https://www.ucl.ac.uk/lbs/claim/view/3150.

153 McQueen, "Born Free," 60.

154 Legacies of British Slave-ownership, "William Alexander Mackinnon," University College London, accessed 17 December 2018, https://www.ucl.ac.uk/lbs/person/view/ 44859 .

155 Legacies of British Slave-ownership, "Robert John Walcott," University College London, accessed 17 December 2018, https://www.ucl.ac.uk/lbs/person/view/6834.

156 Nic Klaassen, "William John Peterswald," Flinders Ranges Research, accessed 17 December 2018, https://www. southaustralianhistory.com.au/peterswald.htm.

157 Legacies of British Slave-ownership, "William Peterswald," University College London, accessed 17 December 2018, https://www.ucl.ac.uk/lbs/person/view/12689.

158 Legacies of British Slave-ownership, "Archibald Stirling the younger," University College London, accessed 17 December 2018, https://www.ucl.ac.uk/lbs/person/view/ 18902.

159 Legacies of British Slave-ownership, "Archibald Stirling the younger."; McQueen, "Born Free," 61.
160 Manning Index of South Australian History, "Place Names of South Australia - S," State Library of South Australia, accessed 17 December 2018, http://www.slsa.sa.gov.au/manning/pn/s/s6.htm.

161 Hans Mincham, "Stirling, Sir John Lancelot (1849-1932)," Australian Dictionary of Biography (Melbourne University Press: Melbourne, 1976), http://adb.anu.edu.au/biography/stirling-sir-john-lancelot-4933.

162 Australian National Botanic Gardens, "Wiles, James (1768-1851)," accessed 17 December 2018, https://www.anbg.gov.au/biography/wiles-james-17681851.html; Legacies of British Slave-ownership, "James Wiles," University College London, accessed 17 December 2018, https://www.ucl.ac.uk/lbs/person/view/16597.

163 Leonie Kramer, "Gordon, Adam Lindsay (1833-1870)," Australian Dictionary of Biography (Melbourne University Press: Melbourne, 1972), http://adb.anu.edu.au/biography/gordon-adam-lindsay-3635

164 City of Ballarat, 'Adaptive reuse of a heritage place - finalist," http://www.ballarat.vic.gov.au/lae/awards-andceremonies/ballarat-heritage-awards/2015-ballarat-heritage-awards/adam-lindsay-gordon-cottage-at-ballaratbotanical-gardens.aspx

165 Westminster Abbey, "Adam Lindsay Gordon," accessed 17 December 2018, https://www.westminsterabbey.org/abbey-commemorations/commemorations/ adam-lindsay-gordon/; Monument Australia, "Adam Lindsay Gordon," accessed 17 December 2018, http://monumentaustralia.org.au/themes/people/arts/display/107210-adam-lindsay-gordon; Blainey, A History of Victoria, 138.

166 Legacies of British Slave-ownership, "Harriet Elizabeth Gordon," University College London, accessed 17 December 2018, https://www.ucl.ac.uk/Ibs/person/view/1301997271.

167 Australian Poetry Library, "Fidelia S. T. Hill," accessed 6 December 2018, https://www.poetrylibrary.edu.au/poets/ hill-fidelia-s-t; Hall, "Writing History, Making 'Race'," 378.

168 Legacies of British Slave-ownership, "Fidelia Hill (nee Munkhouse)," University College London, accessed 6 December 2018, tps://www.ucl.ac.uk/lbs/person/view/584002331; Legacies of British Slave-ownership, "Jamaica Port Royal 9 (Strawberry Hill)," University College London, accessed 6 December 2018, https://www.ucl.ac.uk/ lbs/claim/view/16418.

169 Legacies of British Slave-ownership, "Lucy Savage Sturgis Munkhouse," University College London, accessed 6 December 2018, https://www.ucl.ac.uk/lbs/person/view/ 46036.; Legacies of British Slave-ownership, "Anna Sophia Savage Munkhouse," University College London, accessed 6 December 2018, https://www.ucl.ac.uk/ lbs/person/view/ 46033.

170 Legacies of British Slave-ownership, "Mrs Mary Ruthven (nee Virgo)," University College London, accessed 6 December 2018, https://www.ucl.ac.uk/lbs/person/view/ 2146648869 . 
171 MyHeritage.com, s. v. "Mary Bell Campbell (born Ruthven)," accessed 6 December 2018, https://www.myheritage.com/research/record-1-138030662-1-16/marybell-campbell-born-ruthven-in-myheritage-familytrees?s=575769431; Births, Deaths and Mariages (SA), "Campbell, Reginald Shadwell," book 3 of South Australian Births 1842-1906, 249; Cf. Richard Refshauge, "Campbell, Envidale Savage Norman (1806-1859)," Australian Dictionary of Biography (Melbourne University Press: Melbourne, 1969), http://adb.anu.edu.au/biography/campbell-envidale-savage-norman-3155.

172 Refshauge, "Campbell, Envidale Savage Norman."; ANU Archives, s. v. "Office of the Registrar-General and Office of Titles (Victoria)," accessed 6 December 2018, http://archivescollection.anu.edu.au/index.php/officeof-registrar-general-and-office-of-titles-victoria; Madonna Grehan, "Charles Joseph La Trobe and the Regulation of Everyday Life: Implementing the Births, Deaths and Marriages Registration Act in Victoria 1852-1858," C J La Trobe Society (2015), http://www.latrobesociety.org.au/ LaTrobeana/LaTrobeanaV14n2.pdf.

173 Legacies of British Slave-ownership, "John Knox," University College London, accessed 5 December 2018, https://www.ucl.ac.uk/lbs/person/view/2146641997.

174 Ibid.

175 lbid.

176 Legacies of British Slave-ownership, "Rachael Hanslep then Knox (nee Gordon)," University College London, accessed 5 December 2018, https://www.ucl.ac.uk/lbs/person/view/14620.

177 Legacies of British Slave-ownership, "John Knox."

178 Fernandes, Island Off the Coast, 14; Legacies of British Slave-ownership, "John Samuel August," University College London, accessed 6 December 2018, https://www.uc l.ac.uk/lbs/person/view/11646.

179 Legacies of British Slave-ownership, "John Samuel August."; Fernandes, Island Off the Coast, 14; Altona Homestead, "Early history and settlement," accessed 12 December 2018, http://alhs.com.au/local-history/early-history-and-settlement/.

180 Sendziuk \& Foster, A History of South Australia, 12.

181 e.g. see Alan Pope, One Law for All? Aboriginal people and criminal law in early South Australia (Chicago: Aboriginal Studies Press, 2011).

182 Sendziuk \& Foster, A History of South Australia, 14.

183 South Australian Gazette and Colonial Register, "The South Australian Company," 18 June 1836, 6. (Trove); Deed of Settlement of the South Australian Company (1836).

184 Deed of Settlement of the South Australian Company (1836), Clauses 69, 84.

185 Deed of Settlement; Andrew Brown, "History of George Fife Angas and His Contribution to South Australia," Flinders University, 11 June 2013, http://www.flinders. edu.au/ehl/fms/archaeology_files/dig_library/directed_stu dies/ARCH8404\%20Andrew\%20Brown.pdf.
186 Deed of Settlement of the South Australian Company, first schedule.

187 Ibid., Clauses 62, 65.

188 F. Algar, A Handbook to the Colony of South Australia (London: 1863).

189 Edwin Hodder, George Fife Angas: Father and founder of South Australia (Unwin Bros.: London, 1891), https://archive.org/stream/georgefifeangasf00hoddiala/ge orgefifeangasf00hoddiala_dju.txt.

190 Register News-Pictorial, "Street Corner History."; South Australian Register, "The Mayor's Punchbowl," 2 February 1859, 3. (Trove); Sendziuk \& Foster, A History of South Australia, 13; Advertiser, "The Founder of Adelaide: Honoring Colonel Light," 5 December 1905, 8. (Trove).

191 Register News-Pictorial, "Street Corner History."; Laura Standard and Crystal Brook Courier, "Adelaide's Founders," 9 July 1937, 321. (Trove); Advertiser, "Council to Drink From Historic Bowl on Monday," 4 July 1942, 4. (Trove).

192 Argus, "Adelaide is Certainly the City of Light," 29 July 1954, 22.

193 The City of Adelaide Archives did not respond to author's correspondence.

194 Express and Telegraph (Adelaide), "The Old Colonists' Association: To the Editor," 15 February 1883, 2; South Australian Advertiser, "The Old Colonists' Association: To the Editor," 15 February 1883, 5.

195 Sendziuk \& Foster, A History of South Australia, 16-17.

196 South Australian Register, "Old Colonists' Association," 21 February 1883, 6. (Trove).

197 Geographical Names Act 1991 (SA), ss. 3-4, 6-7.

198 Geographical Names Guidelines (SA), https://www.sa. gov.au/topics/planning-and-property/planning-and-landmanagement/suburb-road-and-place-names/geographical-names-guidelines.

199 Road Naming Policy, Adelaide City Council.

200 Model Policy for the Selection of Road Names 2010, Local Government Association.

201 Naming Rules for Places in Victoria: Statutory requirements for naming roads, features, and localities 2016, Department of Environment, Land, Water and Planning (Vic.).

202 Ibid., 2 (Principle H).

203 Calla Wahlquist and Paul Karp, "Melbourne electorate of Batman renamed after Indigenous activist," Guardian, 20 June 2018, https://www.theguardian.com/australianews/2018/jun/20/melbourne-electorate-of-batman-renamed-after-indigenous-activist.

204 Hall, "Doing Reparatory History," 4-5.

205 I thank Clare Gervasoni of the Geoffrey Blainey Research Centre at Federation University for this information. 